doi: https://doi.org/10.15407/dopovidi2019.04.017

UDC 512.544

\author{
L.A. Kurdachenko ${ }^{1}$, A.A. Pypka ${ }^{1}$, I.Ya. Subbotin ${ }^{2}$ \\ ${ }^{1}$ Oles Honchar Dnipro National University, Ukraine \\ ${ }^{2}$ National University, Los Angeles, USA \\ E-mail: 1kurdachenko@i.ua,pypka@ua.fm, isubboti@nu.edu
}

\title{
On the structure of groups, whose subgroups are either normal or core-free
}

Presented by Corresponding Member of the NAS of Ukraine V.P. Motornyi

We investigate the influence of some natural types of subgroups on the structure of groups. A subgroup H of the group $G$ is called core-free if $\operatorname{Core}_{G}(H)=\langle 1\rangle$. We study the groups, in which every subgroup is either normal or core-free. More precisely, we obtain the structures of monolithic and non-monolithic groups with this property.

Keywords: normal subgroup, core-free subgroup, Dedekind group.

Let $G$ be a group. The following two normal subgroups are associated with any subgroup $H$ of the group $G$ : $H^{G}$, the normal closure of $H$ in a the group $G$, the least normal subgroup of $G$ including $H$, and $\operatorname{Core}_{G}(H)$, the (normal) core of $H$ in $G$, the greatest normal subgroup of $G$, which is contained in $H$. We have

$$
H^{G}=\left\langle H^{x} \mid x \in G\right\rangle
$$

and

$$
\operatorname{Core}_{G}(H)=\bigcap_{x \in G} H^{x} .
$$

A subgroup $H$ is normal if and only if $H=H^{G}=\operatorname{Core}_{G}(H)$. In this sense, the subgroups $H$, for which $\operatorname{Core}_{G}(H)=\langle 1\rangle$, are the complete opposite of the normal subgroups. A subgroup $H$ of the group $G$ is called core-free in $G$ if Core $_{G}(H)=\langle 1\rangle$.

There is a whole series of papers devoted to the study of groups with only two types of subgroups: subgroups with some property $\rho$ and subgroups with a property that is antagonistic to $\rho$ (see, for example, [1-6]). In particular, from the results of paper [3], it is possible to obtain a description of groups that have only two possibilities for each subgroup $H$ : $H^{G}=H$ or $H^{G}=G$. In this connection, a dual question naturally arises on the structure of groups, in which, for each subgroup $H$, there are only two other possibilities: $\operatorname{Core}_{G}(H)=H$ or $\operatorname{Core}_{G}(H)=\langle 1\rangle$. The finite groups having this property had been studied in [7]. Note at once that the groups, whose all subgroups are normal, possess this property.

(C) L.A. Kurdachenko, A.A. Pypka, I.Ya. Subbotin, 2019 
Recall that a group $G$ is called Dedekind, if every its subgroup is normal. The Dedekind group $G$ has the following structure: it is either Abelian or $G=Q_{8} \times D \times P$, where $Q_{8}$ is a quaternion group of order 8, $D$ is an elementary Abelian 2-group, and $P$ is an Abelian 2'-group [8].

Another extreme case that occurs here is the simple groups. In them, every proper subgroup is core-free. This fact immediately shows that the study of groups, in which $\operatorname{Core}_{G}(H)=H$ or $\operatorname{Core}_{G}(H)=\langle 1\rangle$ for each subgroup $H$, makes sense for generalized soluble groups. The two key cases here are as follows: $G$ is a non-monolithic group or $G$ is a monolithic group. Let $G$ be a group. The intersection of all non-trivial normal subgroups $\operatorname{Mon}(G)$ of $G$ is called the monolith of the group $G$. If $\operatorname{Mon}(G) \neq\langle 1\rangle$, then the group $G$ is called monolithic, and, in this case, $\operatorname{Mon}(G)$ is the least non-trivial normal subgroup of $G$.

Our first main result is related to the non-monolithic case.

Theorem A. Let $G$ be an infinite group, whose non-normal subgroups are core-free. If $G$ is nonmonolithic, then $G$ is a Dedekind group.

The following our main theorem considers the monolithic case. Here, we get a much more diverse situation. Separate considerations are required for non-periodic and periodic groups.

Theorem B. Let G be a locally soluble non-periodic group, whose non-normal subgroups are corefree. Suppose that $G$ is not a Dedekind group. Then $G$ is monolithic, the factor-group $G / \operatorname{Mon}(G)$ is non-periodic, $G=\operatorname{Mon}(G) 入 A$, and the following conditions hold:

(i) $\operatorname{Mon}(G)$ is either torsion-free Abelian subgroup or elementary Abelian p-subgroup for some prime $p$;

(ii) $[G, G]=\operatorname{Mon}(G)=C_{G}(\operatorname{Mon}(G))$;

(iii) a subgroup $A$ is Abelian, and $\operatorname{Tor}(A)$ is locally cyclic;

(iv) if $\operatorname{Mon}(G)$ is an elementary Abelian p-subgroup, then Tor $(A)$ is a $p^{\prime}$-subgroup;

(v) if $A$ has finite 0 -rank, then $\operatorname{Mon}(G)$ is an elementary Abelian $p$-subgroup;

(vi) if $B$ is another complement to $\operatorname{Mon}(G)$ in $G$, then the subgroups $A$ and $B$ are conjugate.

In turn, the case where $G$ is periodic also splits into two cases depending on whether the center includes a monolith or not. Recall that a $p$-group $G$ is called extraspecial, if $[G, G]=\zeta(G)$ is a subgroup of order $p$ and $G / \zeta(G)$ is an elementary Abelian $p$-group.

From this definition, we can see that the center of an extraspecial $p$-group $G$ is the least normal subgroup, so that if $H$ is a subgroup of $G$, and $H$ includes a non-trivial $G$-invariant subgroup, then $H$ includes $\zeta(G)$. The equality $[G, G]=\zeta(G)$ implies that $H$ is normal in $G$. In other words, every subgroup of $G$ is either normal or core-free.

Theorem C. Let $G$ be a periodic monolithic group, whose non-normal subgroups are core-free. Suppose that $G$ is not a Dedekind group. If the center of $G$ includes a monolith, then $G=K E$, where $K$ is a cyclic or quasicyclic p-subgroup, $E$ is an extraspecial p-subgroup, $K=\zeta(G)$, and $K \cap E=[G, G]$ is a subgroup of order $p$, $p$ is a prime.

Theorem D. Let $G$ be an infinite periodic locally soluble monolithic group, whose non-normal subgroups are core-free. Suppose that $G$ is not a Dedekind group and the monolith of $G$ is not central. Then $G=\operatorname{Mon}(G) \lambda A$, and the following conditions hold:

(i) $\operatorname{Mon}(G)$ is an infinite elementary Abelian p-subgroup for some prime $p$, and $A$ is an infinite periodic $p^{\prime}$-group;

(ii) $[G, G]=\operatorname{Mon}(G)=C_{G}(\operatorname{Mon}(G))$; 
(iii) whether the subgroup $A$ is locally cyclic, or $A=Q \times B$, where $Q$ is a quaternion group of order 8 , and B is a locally cyclic 2'-subgroup;

(iv) if $C$ is another complement to $\operatorname{Mon}(G)$ in $G$, then the subgroups $A$ and $C$ are conjugate.

Note that if $G / \operatorname{Mon}(G)$ is finite or $\operatorname{Mon}(G)$ is finite and non-central, then $G$ is finite (this follows from Theorem $\mathrm{D}$ ). The last our result gives a description of the finite soluble group, whose non-normal subgroups are core-free. As was noted above, a finite group, whose non-normal subgroups are core-free, was studied in [7]. Our description is more detailed than the description given in Theorem 1 of that paper. We also note that the proof of Lemma 5 in [7] contains a gap (only the case where the both factor-groups $G / N_{1}$ and $G / N_{2}$ are non-Abelian was considered). In addition, there is a mistake there: the fact that $H$ is a subgroup of $T \times A$ does not implies that $H=H_{1} \times H_{2}$, where $H_{1} \leqslant T$ and $H_{2} \leqslant A$. Therefore, we do not use the results of work [7]. We proved of the following result.

Theorem E. Let $G$ be a finite soluble group, whose non-normal subgroups are core-free. Suppose that $G$ is not a Dedekind group. Then $G$ is monolithic.

If the center of $G$ includes a monolith, then $G=K E$ where $K$ is a cyclic $p$-subgroup, $E$ is an extraspecial p-subgroup, $K=\zeta(G)$, and $K \cap E=[G, G]$ is a subgroup of order p, $p$ is a prime.

If the monolith of $G$ is not central, then $G=\operatorname{Mon}(G) \lambda A$, and the following conditions hold:

(i) $\operatorname{Mon}(G)$ is elementary Abelian $p$-subgroup for some prime $p$, and $A$ is a $p^{\prime}$-group;

(ii) $[G, G]=\operatorname{Mon}(G)=C_{G}(\operatorname{Mon}(G))$;

(iii) whether a subgroup $A$ is cyclic or $A=Q \times B$, where $Q$ is a quaternion group of order 8 , and $B$ is a cyclic 2'-subgroup;

(iv) if $C$ is another complement to $\operatorname{Mon}(G)$ in $G$, then the subgroups $A$ and $C$ are conjugate.

\section{REFERENCES}

1. Fattahi, A. (1974). Groups with only normal and abnormal subgroups. J. Algebra, 28, No. 1, pp. 15-19.

2. Ebert, G. \& Bauman, S. (1975). A note of subnormal and abnormal chains. J. Algebra, 36, No. 2, pp. 287-293.

3. De Falco, M., Kurdachenko, L.A. \& Subbotin, I.Ya. (1998). Groups with only abnormal and subnormal subgroups. Atti Sem. Mat. Fis. Univ. Modena, 46, pp. 435-442.

4. Kurdachenko, L.A. \& Smith, H. (2005). Groups with all subgroups either subnormal or self-normalizing. J. Pure Appl. Algebra, 196, No. 2-3, pp. 271-278.

5. Kurdachenko, L.A., Otal, J., Russo, A. \& Vincenzi, G. (2011). Groups whose all subgroups are ascendant or self-normalizing. Cent. Eur. J. Math., 9, No. 2, pp. 420-432.

6. Kurdachenko, L.A., Pypka, A.A. \& Semko, N.N. (2016). The groups whose cyclic subgroups are either ascendant or almost self-normalizing. Algebra Discrete Math., 21, No. 1, pp. 111-127.

7. Zhao, L., Li, Y. \& Gong, L. (2018). Finite groups in which the cores of every non-normal subgroups are trivial. Publ. Math. Debrecen, 93, No. 3-4, pp. 511-516.

8. Baer, R. (1933). Situation der Untergruppen und Struktur der Gruppe. S.-B. Heidelberg Acad. Math.-Nat. Klasse, 2, pp. 12-17.

Received 02.01.2019 
Л.А. Курдаченко ${ }^{1}$, О.О. Пипка ${ }^{1}$, I.Я. Субботін ${ }^{2}$

1 Дніпровський національний університет ім. Олеся Гончара

${ }^{2}$ Національний університет, Лос-Анджелес, США

E-mail: 1kurdachenko@i.ua, pypka@ua.fm, isubboti@nu.edu

ПРО СТРУКТУРУ ГРУП, ПІДГРУПИ ЯКИХ

АБО НОРМАЛЬНІ, АБО ВІЛЬНІ ВІД ЯДРА

Досліджується вплив деяких природних типів підгруп на структуру груп. Підгрупу $H$ групи $G$ називаємо вільною від ядра, якщо $\operatorname{Core}_{G}(H)=\langle 1\rangle$. Вивчено групи, в яких кожна підгрупа або нормальна, або вільна від ядра. Точніше, одержано будову монолітичних та немонолітичних груп з цією властивістю.

Ключові слова: нормальна підгрупа, вільна від ядра підгрупа, дедекіндова група.

Л.А. Курдаченко ${ }^{1}$, А.А. Пьпка ${ }^{1}$, И.Я. Субботин ${ }^{2}$

1 Днепровский национальный университет им. Олеся Гончара

2 Национальный университет, Лос-Анджелес, США

E-mail: lkurdachenko@i.ua, pypka@ua.fm, isubboti@nu.edu

О СТРУКТУРЕ ГРУПП, ПОДГРУППЫ КОТОРЫХ ЛИБО НОРМАЛЬНЫ, ЛИБО СВОБОДНЫ ОТ ЯДРА

Исследуется влияние некоторых естественных типов подгрупп на структуру групп. Подгруппу $H$ группы $G$ называем свободной от ядра, если $\operatorname{Core}_{G}(H)=\langle 1\rangle$. Изучены группы, в которых каждая подгруппа либо нормальна, либо свободна от ядра. Точнее, получена структура монолитических и немонолитических групп с этим свойством.

Ключевые слова: нормальная подгруппа, свободная от ядра подгруппа, дедекиндова группа. 